\title{
Cultural Balkanism: Ivo Andric and Niko Kazanzakis Vis-À-Vis with Kadare
}

\author{
Dhurata Lamcja
}

\section{Abstract}

The analysis of the works of Balkan writers such as Ivo Andric, Niko Kazantzakis, and Ismail Kadare takes on a special significance in terms of assessing cultural Balkanism and its implications. The purpose of this paper is to understand if there is a common theme or shared elements in the literature and the three abovementioned writers of the Balkan countries. The review is based on the qualitative approach of the study, combining analytical method, which is used to collect data from the works of three authors from three different countries of the Balkan Peninsula to better understand the common social, cultural, and literary elements and motives of their work, followed by the comparative method, which is used to further analyze the topic and find counteracts regarding the hypothesis of the existence of the concept of Balkanism in the literature of the different countries of the Penninsula. Each of the authors has created his own reality. The redemption and construction of the ruins are associated with the traditional sacrifice of immurement. The work of Kazantzakis and Andric conveys the fundamental state of pessimism or skepticism towards the new history of mankind. The three authors, share elements in their work, which appears not only as similar literary motifs between them, but also between the Balkan culture from which the authors come from, reflected in modern literature. There is a relationship and interaction between the culture, folklore and mythology of the various countries of the peninsula, thus giving support to the idea of the development of Balkanism.

Keywords: Balkanism, literature, mythology, folklore, literary motifs

\section{Introduction}

Balkanization is a term used today to explain the dissolution of some multiethnic states and the transfer of their powers to dictatorship, ethnic cleansing, and civil war (Pringle, 2018). The term Balkan studies, implicating a science focused on the 
communion of linguistic, historical, and ethnographic features of the people of the Balkans, namely Balkanisms, have started to be used by scholars of the region (Veliaj, 2012). Comparative studies of contemporary Balkan literature today focus on important works of the authors that serve as a starting point for studying how the Balkans are perceived and how regional archetypes are described. The comparative approach to the important works of authors from Albania, Bulgaria, Greece, Romania, and the countries of the former Yugoslavia has continuously prompted scholars to conduct comparative studies aimed at elaborating the relationship between literary and cultural texts and how they serve as meeting points between oral and written narratives, the vacillation of remembrance that modernism and postmodernism face to the point where each of them becomes impossible to distinguish, epitomized by the Greek word "Mythistorema" in the sense of the narrative of the history of a myth.

The Balkans are known for their half-truths, even in the field of science, unfortunately (Veliaj, 2012, pp. 120). If we focus only on the field of cultural heritage, this is clear. It has been about a century and a half that all studies in the field of national culture, of all Balkan countries, suffer from the incorrect presentation of the others. In the field of folklore studies, this is clear. Those who have had the opportunity to visit the libraries of the peninsula and who know its languages find themselves poorly reflected in the books written by neighboring scholars. The initial goal to highlight the values of one nation, if it belongs to it, and to overshadow the others, is not just a fact that scholars from the outside notice, it is also noticeable from the people that live in this territory and mindset.

It is normal for different scholars to reach different conclusions, but it is not so normal, when scholars who come up with different conclusions, have the nationality of the nation for which they claim that ballads take precedence. At this level of knowledge, i.e., scientific knowledge, the Balkans have poorly designed the silhouette of the neighbor, the other, who on a human level is quite close to them. But they have also badly designed themselves, amplifying values. Finally, the complete picture, created by all these approaches, turns out to be inaccurate and does not serve objective recognition (Veliaj, 2012, pp. 121). The exclusive approach and picnicking and the desire to impose a hierarchy of cultural values based on large cultures and small cultures are one of the factors that have hindered the emancipation of scientific thought in the Balkans. However, the analysis of the works of Balkan writers such as Ivo Andric, Niko Kazantzakis, and Ismail Kadare takes on a special significance in terms of assessing cultural Balkanism and its implications. 
The primary purpose of this paper is to understand if there is a common theme or shared elements in the literature and the three abovementioned writers of the Balkan countries. To attain this purpose, the paper is based on the qualitative approach of the study. The first methodology used in this work is the analytical method, which is used to collect data from the works of three authors from three different countries of the Balkan Peninsula to better understand the common social, cultural, and literary elements and motives of their work. The second method of research used in this work is the comparative method, which is used to further analyze the topic and find counteracts regarding the hypothesis of the existence of the concept of Balkanism in the literature of the different countries of the Penninsula. The structure of this paper is made up of the introduction, which helps the reader have a first grasp of the concept of Balkanism; after that comes the analysis, which thoroughly deciphers the work of three of the most well-known writers from three different countries; then comes the discussion, which helps to further analyze the actual commonalities, differences and open debates regarding the topic, while lastly, the paper draws the necessary conclusions.

\section{Analysis}

\section{Niko Kazanzaqis and his work}

Nikos Kazantzakis (1883-1957) was born in a small town on the island of Crete to a wealthy family. Crete, at that time, was still under Turkish rule, and its inhabitants were constantly waiting for the subsequent uprising (Kazantzakis, 1968, pp.34). His dual relationship with his father was not only reflected in his life journey but also his literary work (Bien, 1962). Kazantzakis finalized his masterpieces in the age period of 60 to 70 years. The success of his first works, such as the novel "Serpent and lily" (1906) and the drama "Day Is Breaking," which won the University Prize in 1907 in Athens, reinforced the path he had chosen. The use of phraseological expressions at a time when the Greek people spoke the everyday language, and the written language was utterly unknown, distinguishes these early works of his, especially the work "The Master Builder". As he quoted: "My goal is not a literary achievement but my desire to express a new meaning in life" (Kazantzakis, 1968, p.83).

In 1920 Kazanzaqis considered literature as one of the possible ways of selfactualization, in which he has a great responsibility to himself and the people who trusted him. The elite of society in Greece and everywhere in the Balkans (Serbia, Romania, Albania, or Bulgaria) wanted to return to the respective country's culture by creating masterpieces of Eastern literature and philosophy. Kazantzakis was one of the first authors to support this approach. After returning from Paris and Italy, he 
translated a series of works by Plato, Materlink, Darwin, Nice, Berson, Buckner, Ackerman into modern Greek.

Aesthetic and philosophical views of Nikos Kazantzakis

While analyzing his poetic and autobiographical work, it is understandable that the Greek author chose literature to achieve his lofty goal, namely, to "give as much spirit as he could to his work" (Kazantzakis, 1968, p. 520). However, this was not an easy decision, as it incited internal conflicts on an ongoing basis. Moreover, the room where he wrote in his youth was too small for the dreams of a person aiming to "improve the world" and for his youthful vigor as he writes in poetry:

"Difficulty and sadness are the destiny of a poet because he is forced to use words from an inner realm to give life to something rigid. Every word is a strong shell that holds within itself a great explosive power. To find its meaning, you have to make it explode inside you like a grenade; only in this way can the soul be taken prisoner." (Kazantzakis, 1964, pp. 86).

He reached this conclusion at the end of his life. Combining the poet's mission and personality, Kazantzakis, as a young boy, chose to show his rebellious and stormy nature through his words and his inclination towards literature (Owen, 2003). Literature was for him an "urgent solution of his youth in the face of the tragedy of life" (Kazantzakis, 1968, p. 83) and this kind of art became the only opportunity for expression of this prudent writer. Due to the turbulent developments in the Balkans, in the first half of the century, despite his best efforts, he could seldom reveal himself because he could not withstand the pressures of reality and had decided not to choose a field other than literature.

Fan Noli (1880-1964), who has been an Albanian statesman, poet, church clergyman, historian and composer, has much in common with Kazantzakis and not by chance. Noli, born and raised in the same semi-oriental influential world as Kazantzakis, was influenced by the philosophical turn of the century and the idea of the superhuman. In the same way as Kazantzakis, he was also a politician and held a senior post. He also had extensive knowledge of the Western and Eastern world and culture. Through his work and masterful translations, he has dramatically enriched Albanian literature. He also traveled the world and wrote some of his books in other languages. The commonalities between the authors end at the point where Kazantzakis did not allow himself to be "superhuman," distracted from the primary goal. The soberer he was in his youth, the more important his literature became. On the other hand, Noli had a "stormy" temperament, not among the various fields of activity he aspired to 
but in the expression of talent. Kazantzakis often viewed literature as a mission, as his task on Earth. "I have to hurry to complete my tasks before I disappear underground," he wrote in 1929 (Kazantzakis, 1968, pp. 157). He describes what he calls a task in the following statement:

"Awakening silence, making those who feel humble, happy, extracting precious stones from the mine and distributing them to peaceful families - this is a very high and challenging task. Why? On purpose that the world may not sink into the swamp of comfort, the souls of men should not rot in prosperity. "(Kazantzakis, 1968, pp. 28).

For Kazantzakis, great craftsmanship is a call from nature; and what man should do is live in the most harmony with it and its rhythm. This is probably one of the reasons that Kazantzakis is so closely associated with the traditional, which makes his work appear timeless. His work "Zorba" won the readers' sympathy for his simplicity, with a simple and wonderful hero like Zorba, especially when people and allied forces were singing praises when most of them were involved in wars with modern weapons and literature was the counterweight. The idea of living in harmony with nature is found in almost all of Kazantzakis' work. For example, in his work, "Zorba," the ideal is expressed directly and programmatically:

"Today I understand that it is a sin to violate eternal laws. We have a duty not to rush, not to be impatient and to follow the eternal rhythm of nature faithfully" (Kazantzakis, 1955, pp. 103).

The writer delves into the philosophy and belief from the beginning of the work "Scene" (Klosi, 1991, pp. 42), which is also a philosophical-poetic work; the work "Askitiki" of 1928, and the subtitle "The Saviors of God", which to a large extent represents his creed and finds resonance in his later works. In "The Saviors of God", Kazantzakis wants his aesthetics to formulate basic philosophical questions; this happens with a less "scientific" and more rhetorical language habit. The writer's main task is to explore the world and the soul.

"Only one thing excites me: to understand what is behind the phenomenon, what secret it contains" (Klosi, 1991, pp. 42).

\section{Ivo Andric and his work}

Ivo Andric was born in Travnik in 1892, the formal center of Ottoman administration in Bosnia at the time. Andric attended Wischegradattend primary school. In 1902 he went to Sarajevo to give lectures (Popović, 1989). This was the triangle of his youth: Travnik-Wischegrad-Sarajevo which also was the triangle and the subject of his work. Andric writes of his childhood town in a 1940 sketch: "Staying in Sarajevo and 
later in Zagreb was no longer 'happy"'(Klosi, 1991, pp. 56). In the cities where he studied, Andric got to know other young patriots, writers, and artists (such as the revolutionary "Junge Bosnia" association).

\section{Andrics' Art}

In terms of artistic features in Andric's prose and text, the motive for the static immurement sacrifice can be more closely analyzed. (Klosi, 1991, pp. 68). In Andric, meditative prose prevails over action prose, although the narrator usually avoids the course of an episode. The power of philosophical discourse causes the immediate cessation of philosophical judgments and conclusions. Andric makes extensive use of direct philosophical wisdom by emphasizing once again the meditative nature of his prose. It reminds us of writers like Thomas Mann or Hermann Hesse, who also unfold a meditative-philosophical realistic picture. What these authors have in common is, among other things, the insensitive clarity, the outward calmness, and the resonant tone of the narrative, which is repeatedly historical pessimism in the light of the same European developments. This side of his prose has been extensively analyzed. Naturalism brings a certain calmness to the most vivid situations. This feature should be considered as it shows the chronic tone of the prose; hence this "motionless and indifferent" portrayal of shocking scenes. For example, murder scenes are at the same pace as ordinary situations.

However, the stillness chosen is only an illusion because Andric's fundamental statement strikes at situations, which are crucial, dramatic, and tragic in human life. They are hidden under the cloak of prudent style through actions, motivations, irrational conflicts between species, which are given to them. This is revealed in the characters of Mustafa Magyar, farmer Simán, Alija Djerželez, etc.

For Andric, fabricated time slows down, so it can stand as such despite the centuries. The writer freezes - as in "The Bridge on the Drin" - and thus reproduces it as an "eternal abode." The illusion of modernity appears paradoxically and ridiculously to "speed up" time, to make everything faster or more accessible. Ali Hodscha is well acquainted with and appreciates the philosophy of his ancestors. Therefore, he can not agree enough with the young man to endure the agitation of the latter.

Andric's sense of stopping time also reinforces verbs that express repetitive actions. Related to this is the frequent use of the present tense for past situations, for example, in "Bridge over the Drin":

"This is how the life of the children of the city goes under the bridge and around it in the unintentional play" (Andrić, 1945, pp.13); 
"On the rainy autumn nights, the people who gather in the tavern of Zarija dive into the water, in boredom" (Andrić, 1945, pp.260);

"They return to their old places and sit down again" (Andrić, 1945, pp.295), etc.

The unraveling of this particular time, which is either slow or completely stopped, as well as the things it offers, constitute the key to Andric's work.

\section{Ismail Kadare and his work}

Unlike Kazantzakis and Andric, Ismail Kadare's work has only been translated in the last two decades. He was born in Gjirokastra, Albania in 1936. During World War II, young Kadare was in his hometown, where the Italian and Greek armies passed, and the German army later came to occupy. The autobiography of that time can be found in the 1971 novel "Stone Chronicle".

After the war, Kadare attended primary and secondary school in the city of Gjirokastra. He started writing and publishing poetry very early on. He enrolled at the University of Tirana, studying Albanian Language and Literature. After completing his studies in Tirana, Kadare continued his artistic education at the Gorky Institute in Moscow. Here he came in contact with contemporary or modern European literature. With the breakdown of relations between the Soviet Union and Albania in 1961, Kadare had to drop out of school and return to Tirana (CikoKelmendi, 2009).

However, in the 1960s in Albania, Kadare was primarily known as a successful poet. His collections "My Century," 1964, "Eagles fly high," 1966, "Sunny Motives," 1968, etc. characterized by enthusiasm for socialism, abstractions, and "entanglements," (Misiri, 2015), which were very popular among young people at the time. The poetic collection "Time" published in 1976 marked his farewell to the genre of poetry. This collection contained political poetry, so it focused on Albania's path to communism. "The Castle" and "Stone Chronicle" were written after "The General of the Dead Army", which are also the most important works of Kadare of the 1960s.

\section{Motives in Kadare's works}

\section{The motive of resistance}

The motive of resistance is found in Kadare's most essential poems, such as "Winter Fields," as well as in his early novels. However, this motive is also in the spotlight in later proses. It is a new development in Albanian literature that cannot be seen as a purely personal tendency of a writer (Dado, 2010). The history of Albania and the Albanians was mainly related to the resistance identified in Kadare's work. 
The new literature faced a fundamental question: How can a people without a state, cultural centers, and a uniform religion preserve its language and identity? Indeed, Albanian literature had raised this question since its inception. Unfortunately, the efforts of the National Renaissance poets did not offer an accurate interpretation of history. To raise awareness and stimulate the independence movement, writers such as De Rada ("Milosao," 1836) and Naim Frashëri ("Skanderbeg's History," 1882) idealized the history of Albania before the Turkish occupation in the 15th century, as a prosperous time of the united nation, with a single state.

The resistance of the Albanians against the Turks, the first alliance of Albanian princes and leaders under Skanderbeg, was, in fact, a crucial moment for the Albanians in the Middle Ages. However, there is no evidence for an existing state tradition before this time; on the contrary, historical documents showed the territories under the rule of the Western Balkans, such as Byzantium in Anjous, Naples, etc. Nevertheless, the Albanian people undoubtedly existed in the time of the Roman Empire.

The typical way in which Kadare imitates mythology is related on the one hand to the mythical symbol, which is based on the deep belief that "the earth is born to return to its belly," on the other hand, the writer forms a strong contrast with this faith by objectively discussing the ignorance of Albanians in these matters This tendency that can be called "distortion of the mythical figure" is special in Kadare's works based on the analysis of mythical motives within them (Klosi, 1991, pp. 91).

\section{The Ottoman Empire, a model of the totalitarian state}

Even if Kadare's works, which can be assigned to this topic, when Albania belonged to the Ottoman Empire, are not mentioned simply as "Albania and the Ottoman Empire." Typologically two polar types of history need to be processed in writing. The author must either respect them as much as possible or take from history only the impetus for free fiction space. These extremes can be roughly divided. Utilizing hundreds of other history-shaping opportunities, Kadare tends to move in the second direction. This is also possible if we compare his "historical" prose with the works of other Balkan authors, for example, Andric's "The bridge on the Drin" or Kazantzakis' "Freedom or Death." These two novels are dominated by history and authoritarian considerations in history (Klosi, 1991, pp. 91). In contrast, in Kadare's works, such as "The Red Paschals" and "The Palace of Dreams," as well as some short stories, history is more the starting point for a completely new structural construction than for the fictional literary material. 
It is not surprising that such prose often provokes controversy, on the part of historians, because of the changing historical facts. However, this issue was resolved, as in the above works of Kadare, the historical facts addressed did not exceed 200 years ago; that is, they were verifiable. Also, for the addressed personalities, such as Ali Pasha Tepelena, the biography already exists.

Kadare was not interested in the story itself but rather its adaptation, design, and interpretation. Adaptation is an excellent trend in Kadare's overall values. Also, in the texts mentioned above, the author gradually designs the model of a superstate based on modern historical states (Klosi, 1991, pp. 92). The author creates his "kingdom," a familiar and yet new country, which on the one hand, is based on history, but on the other hand, is based on change. Such places have appeared frequently in literature (T. Hardy, W. Faulkner, etc.). In addition to the particular imaginary consequences of the writer who appears seemingly independent of contemporary events, they prove a central theme through repetitive variations or enrichment of the same events.

\section{Autobiographical motives}

Because Kadare had worked as a journalist for a long time, journalism has influenced his work between autobiographical fiction and journalism. In addition to a series of reports, travels, sketches, Kadare has also written short stories, such as "Europe of Kings," "The Last Winter", etc. to complement further the portrait of the writer and his original stylistic work in the constant interaction between reality and fiction. To underline history, mythology, and fiction we can see the work "Stone chronicle", which is written in the first person and has apparent autobiographical features. "Stone chronicle" is the chronicle of the author's hometown, Gjirokastra, during World War II. In this work, the reader is involved in the fantasy world of the child; the appearance or position of the chronicler is original and idiosyncratic.

\section{Discussion}

In addition to Ismail Kadare, well-known Balkan authors have successfully used ballads in literature. If in the nineteenth century the authors tried to present the popular creations they had made themselves, in the twentieth century, the trend was the opposite: writers referred to ballads and republished them for the wider national and international reader.

Even if Andric and Kadare have similar historical constellations, different concepts of history unfold in their works. For Andric, there have always been conflicts between Bosnian "Turks" and Christian natives, but these conflicts do not define Bosnia's history. In "The bridge on the Drin" or "Viziers and Consuls" often the events are set in 
this "Land of hatred", where the common understanding and action of the spiritual leaders of the four religions takes place.

Andric considers the Ottoman occupation and the coexistence of people with different histories to be a reality, which will be positively assessed in the face of the destructive conflicts of the modern era. However, for Kadare, this has to do with the Turkish occupation of Albania, a time when Albania was abandoned by Christian Europe, which brought a lot of pain, a lot of lost things, a new calendar, which changes turns time "600 years back" (Klosi, 1991, pp. 91), "a nation that kept women covered" (Klosi, 1991, pp. 91), etc., illustrate such a historical perspective.

In the works "Journey through history," "The Castle", or "The bridge with three arches", it seems that Albania was ready to be divided at the time of the incident. A similar conflict is also reflected in the novel The Evil Year, although the contrast is not schematic. A "pre-Turkish" Albania was very similar to the then progressive part of Christian Europe. The blind, unpredictable violence of the state and the often vague bureaucratic structures embodied in the Ottoman Empire form another important motive that brings Andric and Kadare closer together. This is evident in Andriç's "The Damned Court" (1954) and Kadare's "The Palace of Dreams" (1979). The viziers in these works are powerless against the arbitrary and obscure state machinery. The authors reveal highly interconnected figures, which stem from the darkest histories of Southeast Europe.

According to a comparative study by Granit Zela (2016) between the novels "The Bridge with Three Arches" (1978) by Ismail Kadare (1936-) and "The bridge over the Drin" (1945) by Ivo Andric (1892-1974) that the two main constituents of the two literary works are myth and history. Kadare, however, begins with the myth and sees history through it. In contrast, Andric begins with the history, and the bridge or the myth of sacrifice over the bridge is just a structural node of four centuries of Bosnian history. The main meeting point of the two authors is mythology, while history (power, money, etc.) brings different perspectives of the authors in accordance with their cultural and literary background. Both works use the metaphor of Albania and Bosnia as a bridge between East and West and refer to the pan-Balkan myth of the female body walled up or immured on a bridge, a myth that exists widely in the Balkans.

Kadare's great attraction to the legend of immurement was also evident in the essay book "The Autobiography of the Albanian People in Verses," a book in which the author meditates on the authorship or co-authorship of the peoples of the Balkans (mainly the Albanian people) in creating of the treasury of Balkan legends and folklore 
arguing against the Slavic claims of authorship. He brings arguments in favor of the Albanian authorship of these legends, among which he distinguishes the Legend of the Wall (Shkodra Castle) and The Legend of the Word of Honor (Besa) (Constantine and Doruntina).

According to Kadare, "both legends served world literature to create poetry, drama, and novels in several languages" (Zela, 2016, pp.194). According to Jacob Grimm, "the legend of the wall is one of the most touching songs of all peoples and of all times" (Kadare, 2002, pp.23). According to Kadare, this legend is Albanian based on the historian Marin Barleti of the sixteenth century; the latter wrote that he read the legend in the chronicles written in the local language. He concluded that in no other region of the Balkans, this legend is as popular as in the Albanian territories; the motive of the besa encountered in the ballad, a motif that is one of the most powerful acts of drama, constitutes the main difference between the Albanian and the Slavic version. According to Kadare:

In the Slavic version, which claims to be called a parent variant, in particular, the verse "Two brothers break the promise," the words "vjeru pogazio" do not make sense in the context of the ballad. These words are a mistranslation of the phrase "breaking the besa" of the Albanian ballad, where the word "besa", "which has no original counterpart in the Serbo-Croatian language, was mistakenly replaced with the word faith (religion), which does not have a connection. Such borrowing is in favor of the thesis that the original variant, in this case, is the Albanian and not the Slavic one "(Kadare, 2002, pp.30-31).

All three authors used the myth of construction sacrifice. Werke's analysis (Kadare, 2002, pp. 126) deals extensively with the treatment of mythology in their works. As for the model, each author created the material for the ballad from the wall motif. Andric led the ballad in his novel only as a secondary and ethnographic episode. Kadare often uses the conventional plot at every step of his subject. However, he takes into account the deeper meaning of the myth. Kazantzakis deals with the myth (Kadare, 2002), the dilemma of the ballad, the awareness between the mythical necessity and the loss of the loved one, the appearance of people in a love conflict, the self-denial of the punishment for the immorality of the builder and his girlfriend, Smaragda. Andric integrates the building sacrifice motive into realistic, even naturalistic scenes as he saw the conventional legend as an invention and dismissed the story as a child. The need for sacrifice, the "white power of the foundations," the

\footnotetext{
${ }^{1}$ Besa (pledge of honor) is an Albanian cultural precept, usually translated as "faith" or "oath" that means "to keep the promise"and"word of honor".
} 
harmony of the building with the land, the river, nature, the myth are fully included in the vision of the work.

Kadare uses the myth in another way by "distorting" individual mythologies and showing their weaknesses. In this sense, he is closer to him than Kazantzakis is because this is presupposed by the opposite form of the myth. Kadare shows a reality that violates the myth or his mythical counterpart. However, Kadare differs significantly from the other two authors in presenting a "stubborn" prose (Klosi, 1991). Compared to the believable or realistic images of Andric and Kazantzakis in "Bridge over the Drin" and "Greek Passion", he writes a modern criminological story, the plot of which is taken from a European ballad on an ancient island. Meanwhile, against the supposed background of ancient Albania, modern characters eternally review the current readiness of the narrator.

\section{Conclusions}

As for the philosophical attitudes of the three authors, we can say that the literature of Kazantzakis and Andric conveys the fundamental state of pessimism or skepticism towards the new history of mankind. This comes not only as a reflection of the meaningless and tragic modems of developments in Europe and around the world but generally as a response to the search for the meaning of human existence.

In terms of literary and artistic profiles, each of the authors has created his own reality. This conclusion emerges through an analysis of the degree of similarity of the work with reality or with a popular myth or ballad. Realism, the creation of forms as a second nature are standard features of art and literature (Zalambani, 2003), evident in Andrić's essay on Goya. Kazantzakis here has a similar definition: "I try to bring as many issues back to my soul." Furthermore, Kadare responded to the criticism of his novel "The Great Winter" that "literary work, with its flaws and advantages, is not a hypothesis, but a single reality" (Klosi, 1991, pp. 315). The three authors agree on this point, but the paths they follow to create the "second reality" differ. In all three authors, the term realism is most commonly used for Andrić. "I do not know if my work can be considered realism, but I believe it is real" (Klosi, 1991, pp. 316). Through the impressions of the realist writer, whose photographs match the real world, Andric conveys historical accuracy, the objectivity of naturalism, and general statements, wisdom and sayings.

As for the victim, in Kazantzakis' work, the sacrifice is a response to the legend rather than the traditional sacrifice. In "The Master Builder," the sacrificed character is a young, courageous and innocent woman. On the other hand, the victims in the 
bridge's pillar over the Drin are farmers, who did not like the massive structures of the bridge and even sabotaged them. However, the redemption and construction of the ruins are associated with the traditional sacrifice of immurement. Here is an attempt by Andric and Kadare to experiment with the sacrifice mentioned in Kazantzakis' "The Greek Passion".

All these shared elements in the works of the three authors, which appear not only as similar literary motifs between them, but also between the cultures from which the authors come from, reflected in modern literature, allow us to think that in fact, there is a relationshp and interaction between the culture, folklore and mythology of the various countries of the peninsula, thus giving support to the idea of the development of Balkanism.

Based on this conclusion, one of the appropriate recommendations for future academic work in this field would include analyzing modern literature developed in the Balkans during the XXth century as genuine literature that goes beyond ideological intent, although obstructed from the latter. Balkanism in literature should be explored in more detail by viewing it through a cultural scepter as a whole and as a shared cultural element of a grouping of nations which, beyond the geographical proximity, have a series of proximities in their cultural aspects, which are often neglected as a result of political relations between the nations.

\section{References}

[1] Andrić, I. (1945). The Bridge on the Drina. Belgrade: Zsolnay.

[2] Bien, P. (1972). Nikos Kazantzakis. New York: Columbia University Press.

[3] Ciko-Kelmendi, M. (2009). Kadare ndryshe. Tiranë: Naimi.

[4] Dado, F. (2010). Letërsi e painterpretuar: Qasje teorike ndaj realizmit socialist. Tiranë: Bota Shqiptare.

[5] Kadare, I. (2002). The Autobiography of the albanian people in verses. Tirana, Albania: Onufri Publishing House.

[6] Kazantzakis, H. (1968). Nikos Kazantzakis: A Biography Based on his Letters. New York: Simon and

Schuster.http://doi.org/10.2307/2494006.

[7] Kazantzakis, N. (1964). Toda Raba. New York: Simon and Schuster.

[8] Klosi, A. (1991). Mythologie am Werk: Kazantzakis, Andrić, Kadare. Munich: Verlag Otto Sagner. Avaible at: https://library.oapen.org/bitstream/id/21a3d69e-c725-4c11b503a0976a175eb1/1003744.pdf (accessed 25.06.2021). 
[9] Misiri, L. (2015). Myth and Antimyth in the Fictions of Socialist Realism in Albania. European Journal of Language and Literature Studies, vol. 1, ch. 2. Avaible at: https://journals.euser.org/files/articles/ejls_mayaug_15/Laureta.pdf (accessed 23.06.2021).

[10] Owen, L. (2003). Creative Destruction: Nikos Kazantzakis and the Literature of Responsibility. Macon, Ga: Mercer University Press.

[11] Popović, R. (1989). Ivo Andrić: A Writer's Life. Belgrade, Yugoslavia: Ivo Andrić Endowment.

[12] Pringle, RW (2018). Balkanization. Encyclopedia Britannica.https://www.britannica.com/topic/Balkanization

[13] Veliaj, 0. (2012). The Albanian ballad in the balkanic context. Avaible at: https://docs.google.com/file/d/0Bz1NpApIa1A6bEpBSIViRWl2TWs/edit?r esourcekey=0-gGeg58o4z20TCfKPCaHwqQ (accessed 24.06.2021).

[14] Zalambani, M. (2003). Dall'avanguardia al realism socialista. Rome: Carocci.

[15] Zela, G. (2016). Myth and History in the 'The Three-Arched Bridge' and 'The Bridge on the Drina' of Ismail Kadare and Ivo Andric. Rome, Italy: Academic Journal of Interdisciplinary Studies MCSER Publishing. Vol.5, N0.3 SI, 2016. Avaible at:

https://www.richtmann.org/journal/index.php/ajis/article/view/9779 (accessed 06.07.2021). 